\title{
The Corruption of Local Placeman Based on White Collar Crime Criminological Point of View (The Case Study in Klungkung Regency)
}

\author{
Ni Kadek Satyam Krisna Parijata ${ }^{1,}$ Putu Ayu Nadya Mahaswari ${ }^{2}$, I Putu Windu Mertha \\ Sujana $^{3}$ \\ \{satyamkris16@gmail.com,nadyamahaswari25@gmail.com², windu.mertha@undiksha.ac.id ${ }^{3}$ \} \\ Universitas Pendidikan Ganesha, Indonesia ${ }^{1,2,3}$
}

\begin{abstract}
White Collar Crime was a type of corruption crime that was committed by individual or group that had possition to abuse the authority. It showed that, it was not only poverty factor was the background of corruption but the abuse of authority. The problem of this article was the cause factor and the control to decrease the corruption of local placeman based on white collar crime criminological point of view the case study in Klungkung regency. The purpose of this case study is to investigate the factors to influence the corruption based on white collar crime criminological the case study in Klungkung regency and how to handle it. The research method was qualitative method. Based on the result of analysis, there were four factors of white collar crime such as historical factor, opportunity factor, life style factor, and potency (character) of human. The control of white collar crime was committed by preventive and repressive.
\end{abstract}

Keywords: Criminology, Corruption, Local Placeman

\section{Introduction}

Today the term of Corruption is no strange to Indonesian society and is considered a phenomenon of social crime. Almost every day there are news related to corruption cases in this country. White collar crime is a type of corruption or arguably a white-collar crime. This term makes corruption is concerned because of people who have a position that is regarded by society as people who have high intellect, but unwittingly they also cause poverty in this country. It can be said that not only the poverty factor that is the background to the crime of corruption, but the prosperity and luxury factor is the driving factor of people commit crime from their positions[1]. Until now, the efforts to decrease corruption have not produced a sickening result; in contrast, corruption crime is increasingly spreading not only to the central government but also at the regional level. The development of corruption crime appears to be increased in terms of quantity and quality. This makes corruption in Indonesia not an ordinary crime but is seen as an extra ordinary crime. Corruption is classed as extra ordinary crime[2].

According to Lerry J. Siegel, in the field of economic activities the form of criminal law violations is distinguished into two, namely white collar crime and organized crime[3]. Both forms of violation of the law are often considered the same, can use their positions to commit a criminal offence. Currently white collar crime is not only focused on the government, but on the private sector or corporations that are legal entities[4]. 
Criminology is a science in studying evil. Viewed from a criminological point of view, white collar crime can be caused by occupational crime and corporate crime[5]. Occupational crime consists of offences committed by individuals linked to his/her position for his own benefit, while corporate crime consists of violations committed by the corporation and its employees for corporate purposes[6].

White Collar Crime is a crime associated with a legitimate position, so it is as if the prosperity it has comes from his office. This crime is symbolized by the term "white collar" signifying the legal position. In its development, the interpretation of the office is no longer a position obtained from the state, but also a position in a legal entity (corporation). A person who gains office will have the authority or power to do something.

Corruption certainly has a devastating impact on the State. The corruption case can be caused by many driving factors, such as the number of representatives of the people, especially local placemans who are still malfunctioning in using their positions or powers. Feel that the salary earned has not felt sufficient and with the opportunity that facilitates the absence of corruption, in addition to the lack of transparations carried out in every activity by local officials. This is the basis that can trigger fraud to commit corruption by local officials.

The law is often considered a product of politics or policy. This paradigm of positivism is one of the reasons why law and enforcement are lagging behind. In fact, white collar crime in the form of its existence is corruption which also includes extraordinary crimes in the positive laws of Indonesia. Extraordinary crime in terms of its handling requires extraordinary properties as well. Terrorist and narcotics crimes that constitute exceptional crimes in Indonesia can be upheld until the death penalty, while corruption is not. The existence of White Collar Crime is a corporate crime whose kind very rarely continues to the green table of the criminal realm. This kind of situation is becoming a new problem in the legal world. The law in Indonesia is often labeled as a symbol of rigidity that only races against the text of the legislation. In addition, the punitive Funding Model began to be widely criticized. It is high time the rigidity of this legal nature was useful in dealing with the White Collar Crime. The purpose of the law which includes justice and certainty becomes absolute in the enforcement of White Collar Crime[4]. Based on this, the author raised the issue related to the causes of corruption crimes as well as efforts to counter the corruption of local officials seen from a criminological point of view of white collar crime. It is expected that with the known factors of the cause of corruption crimes as well as efforts to counter corruption can be input for the government to formulate regulations or laws that can lower the level of corruption in Indonesia, especially the local government in Klungkung Regency.

\section{Method}

The research approach used in this study was a qualitative approach. In the study used a qualitative approach to fit the problems that will be reviewed in this study. This research was conducted by collecting the deepest data and conducting an accurate analysis of the causes of corruption and efforts to counter the corruption of local placeman based on white collar crime criminological point of view (the case study in Klungkung Regency).

This research was a research method with data collection conducted with literature, this research collects data and information used various library sources that have been observed in advance. The results of these data were then through the diting stage of the data and the evaluation of the data. Based on this stage, obtain the data that can be presented in the form of a description of the causes of corruption and how to counter corruption crimes against local placeman (the case study in Klungkung Regency). 
The data was presented in the form of a description of the causes of corruption and how to counter corruption crimes against local placeman (the case studies in Klungkung Regency) used a normative juridical and empirical juridical approach. The result of the data was presented in a descriptive form and then the data will be interpreted or interpreted at the end of the research or analysis of the data, it was done in order to conduct a discussion that will be analyzed qualitatively, after which will draw conclusions about the data that has been described.

\section{Result and Discussion}

Based on the data from KPK website in 2015-2020 there was the data of white collar crime :

Table 1. White Collar Crime Cases in 2015-2020

\begin{tabular}{lcccccc}
\hline \multicolumn{1}{c}{ Jabatan } & 2020 & 2019 & 2018 & 2017 & 2016 & 2015 \\
\hline $\begin{array}{l}\text { The member of } \\
\text { DPR and DPRD }\end{array}$ & 17 & 10 & 103 & 20 & 23 & 19 \\
\hline $\begin{array}{l}\text { Head of Institution } \\
\text { Ministry }\end{array}$ & 0 & 2 & 1 & 0 & 2 & 3 \\
\hline Ambassador & 0 & 0 & 0 & 0 & 0 & 0 \\
\hline Commissioner & 0 & 0 & 0 & 0 & 0 & 0 \\
\hline Governor & 0 & 1 & 2 & 1 & 1 & 3 \\
\hline Regent and Vice Regent & 4 & 18 & 30 & 13 & 9 & 4 \\
\hline Echelon I/II/III & 7 & 26 & 24 & 43 & 10 & 7 \\
\hline Judge & 0 & 0 & 5 & 3 & 1 & 3 \\
\hline Prosecutor & 0 & 3 & 0 & 1 & 3 & 0 \\
\hline Police & 0 & 0 & 0 & 0 & 0 & 0 \\
\hline Lawyer & 0 & 1 & 4 & 0 & 1 & 2 \\
\hline Private & 12 & 59 & 56 & 28 & 28 & 18 \\
\hline Other & 15 & 33 & 31 & 13 & 21 & 3 \\
\hline Corporation & 0 & 1 & 4 & 1 & 0 & 0 \\
\hline \multicolumn{1}{c}{ Total } & 55 & 154 & 260 & 123 & 99 & 62 \\
\hline
\end{tabular}

Data Source : https://www.kpk.go.id/id/statistik/penindakan/tpk-berdasarkan-profesi-jabatan.

Based on the data it can be known that white collar crime is generally carried out by people who have positions as well as an established economy. The opportunity in the office opens up the possibility of a large number of white collar crime crimes.

Based on Law No. 20 of 2001, there are basically 30 forms/types of corruption crimes. Of these 30 forms, it is divided into 7 large groups, namely (1) deeds that inflict financial losses on the state; (2) bribery bribes; (3) embezzlement in office; (4) blackmail; (5) deed of deed; (6) conflict of interest in procurement and (7) gratuity. The mode of corruption can vary depending on the public officials involved in corruption[7]. According to Andi Hamzah, corruption mode is the way perpetrators commit corruption acts. Almost all officials have been involved in corruption, there are at least nine modes of corruption that can be done by regional officials in his position as regional head. First, corruption through the budget. Second, the possibility of collusion between rulers and entrepreneurs, especially in the field of business. Third, procurement of goods that often happens mark-ups. Fourth, tax receipts often do not go into typical countries. Fifth, registration of government employees with improper levies. Sixth, any permit management. Seventh, utilization of aid and other agency 
programs. Eighth, carry out fictitious activities or ask for part of the assistance received by the community. Ninth, darken the help received[8].

Of the nine modes, reported from detiknews.com example of corruption mode that has occurred in Bali that befell the former Regent klungkung is the mark-up of project funds. This happened when I Wayan Chandra was found guilty of corruption, receiving gratuities and money laundering which was sentenced to 12 years in prison by Denpasar District Court in 2015. The case of corruption was proven to enrich himself Rp. 1.9 billion, where the case began on May 22, 2006 when Candra was the Regent of Klungkung, at that time he published the Decree of the Regent of Klungkung No. 183 of 2006 on the Establishment of the Location of The Construction of The Pier in Klungkung Daratan located in the former Galian C Gunaksa and Tangkas Village covering an area of 50 hectares. But in the land acquisition for Gunaksa Pier there is a budget leak here and there[9].

The article 3 of the Corruption Crimes Act above implies that the perpetrator of a corruption offence must hold a position or position. Then the position or position automatically has authority. Thus the misuse of authority, opportunity and means existed because such position or position uses the authority, opportunity or means attached to the position or position occupied by the perpetrator of a corruption crime for any other purpose than the purpose of granting such authority, opportunity or means[10].

If talking about eradicating corruption is not as easy as turning the palm, there needs to be extraordinary effort. Satjipto Rahardjo argues that eradicating corruption can no longer use ordinary ways of acting and thinking, but should be the opposite of acting and thinking amazingly[11]. It must therefore grow the courage of law enforcement officers to make juridical leaps and balance with the public's legal consciousness to accept verdicts that are out of the ordinary.

The evolving criminology theory can be classified as the cause of white collar crime against local officials in case studies in Klungkung Regency, namely differential association theory. the contributing factors to the crime of corruption abuse of authority in office are: firstly judging by historical factors, Sutherland argues that crimes are learned from human behavior that can be taken from historical factors, so as to explain the causes of the crime[12].

In addition, Gabriel Tarde argues that the crimes committed by a person are the result of impersonation of crimes that have existed in society. The history of corruption in Indonesia began during the Dutch colonial period. Officials in the colonial VOC trade union committed corruption, collusion and nepotism that caused the VOC to go bankrupt with debts of 136.7 million guilders. The VOC finally disbanded on 31 December 1799 after standing for approximately 197 Years. Agus Rahardjo, Chairman of the Corruption Eradication Commission conducted a research that the behavior of corruption since colonial times has made a new habit. White collar crimes committed by VOC members in office made corruption and collusion can be studied repeatedly by its members. This impersonation process turns out to transmit actions outside the group, especially to local officials[13].

The second is the opportunity in the form of the position obtained by the perpetrator and the lack of understanding of the administration in his work so as to cause fraud in the implementation of his work. Coleman argues that when the presence of office and means creates opportunities and is considered to be the only method to still achieve wealth, or in other words "fear of falling" is a strong motivation for the perpetrators of the white collar crime[14].

The three consumptive lifestyle factors, corruption is consumer behavior that is not 
offset by adequate income can encourage a person to take various actions to fulfill his or her needs, including with acts of corruption, this can be driven by lifestyle such as by maintaining a prestige and high lifestyle, an official committing corruption to obtain what he wants, an official is compelled to commit corruption if there is an opportunity to do so.

The fourth is a factor of human potential as well as the main cause is of human nature. The phrase "no human being is perfect" may indeed be true. That to be honest with people, must have been wrong. Where the lack of exemplary attitude of the leader in a formal or informal institution has important influence for his subordinates. If the leader cannot set a good example in front of his subordinates, then most likely his subordinates will take the same opportunity as his superiors. When viewed in terms of corrupt behavior, the causes of corruption can arise from the motivation in him that can be said as the desire, intention or awareness to do.

If the orientation is a necessity, when the need is sufficient, it will stop doing. But if orientation is greed, it will never stop and there will be no complacency. These four aspects of criminology make white collar crime against local officials so difficult to uncover that it requires special, extra, and serious treatment to deal with.

The efforts to counter corruption crimes against local placeman in Klungkung regency in the white collar crime criminology, the authors used the theory of crime countermeasures, namely:

1. Preventive Effort

Preventive efforts such as social education in order to develop the social responsibility of the community, the work of the community through moral education, religion and so on. Preventive efforts can be made by[15]:

a. The Increase internal supervision on the finances of local officials in Klungkung Regency. This supervision aims to ensure that all regional budgets can be used to the maximum without embezzlement. This can ensure that the implementation of government runs in accordance with the expected objectives and objectives. This supervision is carried out starting from the audit process, review, evaluation, monitoring, and other supervisory activities to the implementation of budget tasks and functions in order to provide adequate confidence that the activities have been carried out in accordance with the indicators that have been established. This supervision is carried out to prevent fraud from occurring again, resulting in valuable output to be input of local officials in improving the management and financial accountability of the region in the future..

b. Conducting regular hand-catch operations by the KPK, Law No. 30 of 2002 on Corruption Eradication Commission makes the KPK has a very important role in the eradication of corruption, especially white collar crime because the KPK is independent or free from the influence of any party. KPK has the authority to conduct regular Hand Capture Operations (OTT) against local officials to see if white collar crime is still common in government and corporate environments[16].

c. Improving the electoral qualifications of local officials, in general a position holds a very important and influential role in a position. The selection of local officials must be honest and fair with what was previously attended during the nomination and during the inauguration as a local official. This, it needs to be done so that everyone who has a competent position in their field.

This minimizes the chances of a white collar crime against local officials. Because basically, someone who has held office must have high integrity and regardless of nepotism 
factor. Because a good society in the future depends on a good and honest leader. Good and honest leaders can support a more prosperous society. Therefore, the problem of corrupt behavior abuse of authority in office should be taken into attention in order to form a more prosperous society..

\section{Repressive Effort}

Efforts are made to deal with the perpetrators of crimes such as by sanctioning in the form of criminal, prevention and social protection. The application of criminal sanctions related to white collar crime contained in Article 3 of Law No. 20 of 2001 on the Eradication of Corruption Crimes states that "Any person who is with the purpose of benefiting himself or another person or a corporation, abuses the authority, opportunity or means available to him because of a position or position that could harm the state's finances or the economy of the country. The legal definition of 'White Collar Crime', White Collar Crime is iusly constitutum stipulated in Law No. 31 of 1999 Article 3, which reads: "Setiap orang yang dengan tujuan menguntungkan diri sendiri atau orang lain atau suatu korporasi, menyalahgunakan kewenangan, kesempatan atau sarana yang ada padanya karena jabatan atau kedudukan yang dapat merugikan keuangan negara atau perekonomian negara, dipidana dengan pidana penjara seumur hidup atau pidana penjara paling singkat 1 (satu) tahun dan paling lama 20 (dua puluh) tahun dan/atau denda paling sedikit Rp. 50.000.000,00 (lima puluh juta rupiah)dan paling banyak Rp. 1.000.000.000,00 (Satu Miliar Rupiah)"'[4]. As well as supervision that needs to be increased in preventing corruption committed by officials or civil servants as well as building good and clean morals within a person, it is a very effective countermeasure that can be done from yourself.

\section{Conclusion}

Corruption is one type of white collar crime or white-collar crime. Some of the factors that influence corruption are reviewed from criminology, namely, judging by historical factors, opportunity factors, lifestyle factors, and potential factors of human beings resulting in the abuse of power in serving as a local government. In this case, there are nine modes of corruption that can be done by local officials. First, corruption through the budget. Second, the possibility of collusion between rulers and entrepreneurs, especially in the field of business. Third, procurement of goods that often happens mark-ups. Fourth, tax receipts often do not go into typical countries. Fifth, registration of government employees with improper levies. Sixth, any permit management. Seventh, utilization of aid and other agency programs. Eighth, carry out fictitious activities or ask for part of the assistance received by the community. Ninth, darken the help received. From various factors and modes carried out by local officials in Klungkung Regency in committing this corruption crime, efforts are needed in tackling White Collar Crime in Corruption Crimes against. Local Officials. Efforts that can be made in tackling corruption by local officials with preventive and repressive measures, namely increasing internal supervision on the finances of local officials, this supervision aims to make all budgets of the regional budget can be used to the maximum without embezzlement, Conducting regular hand-arrest operations by the KPK, Improving the qualification of local officials elections as well as the provision of sanctions in the form of criminal, prevention and social protection. 


\section{References}

[1] J.E. Sahetapy, Kapita Selekta Kriminologi. Bandung: Alumni, 1979.

[2] M. S. Prof. Dr. Hj. Mien Rukmini, S.H., Aspek Hukum Pidana Dan Kriminologi (Sebuah Bunga Rampai). Bandung: PT Alumni, 2009.

[3] I. D. M. Suartha, Hukum Pidana Korporasi. Malang: Setara Press, 2015.

[4] F. F. W. Lestari, "Eksistensi 'White Collar Crime' Di Indonesia: Kajian Kriminologi Menemukan Upaya Preventif," Unitri, vol. 6, no. 1, p. 85, 2016.

[5] A. Prakoso, "Kriminologi dan Hukum Pidana," Fak. Huk. Univ. Jember, vol. 1, no. 1, p. 1, 2017.

[6] J. S. Runturambi, "Sisi Kriminologi Pembalakan Hutan Ilegal: Suatu Telaah Awal," Kriminologi Indones., vol. 3, no. 1, p. 16, 2003.

[7] M. H. F.Rahman, Gurito Korupsi Pemerintah Daerah. Yogyakarta: Kaukaba Dipantara, 2018.

[8] Nur Atnan, "Fenomena Korupsi Pejabat Publik di Jawa Tengah dan Cara Mengatasinya," Fenom. Korupsi Pejabat Publik di Jawa Teng. dan Cara Mengatasinya, pp. 165-166.

[9] A. Saputra, "Diperberatkan, EksBupati di Bali dibui 15 tahun di kasus korupsi," Denpasar, 2015. [Online]. Available: https://news.detik.com/berita/d- 3040734/diperberat-eks-bupati-di-balidibui-15-tahun-di-kasus-korupsi.

[10] E. Setiadi, "Kriminalisasi Kebijakan dan Bekerjanya Hukum Pidana," Bandung, 2006.

[11] Satjipto Raharjo, Membedah Hukum Progresif. Jakarta: UKI Press, 2006.

[12] H. D. ; N. Qamar, "Penerapan Teori-Teori Kriminologi dalam Penanggulangan Kejahatan," Pandecta UNNES, vol. 13, no. 1, p. 15, 2018.

[13] A. Bernadius, "Ketua KPK: Korupsi Adalah Perilaku Warisan yang Ditinggalkan Belanda," 2017. [Online]. Available: https://www.rappler.com/indonesia/berita/178292-agus-raharjokorupsi- perilaku-kolonial-belanda.

[14] M. Zakiyah, "Semantik Prototipe Korupsi: Kajian Linguistik Kognitif," Retorika, vol. 11, no. 2, p. $165,2018$.

[15] A. Nawawi, Bunga Rampai Kebijakan Hukum Pidana (Perkembangan Penyusunan Konsep KUHP Baru). Jakarta: Kencana, 2010.

[16] Riski Wulandari;Sagung Putri M.E Purwani, "Kewenangan Komisi Pemberantasan Korupsi Menangani Tindak Pidana Korupsi Yang Di Atur Dalam RUU KUHP," Ilmu Huk., vol. 8, no. 5, p. 10, 2019. 